\title{
Oviposition preference and larval performance of sugarcane borer in eight sugarcane genotypes
}

\author{
Preferência de oviposição e desempenho larval da broca-da-cana em \\ oito genótipos de cana-de-açúcar
}

\author{
Guilherme Vieira Pimentel ${ }^{1 *}$, Adriano Cirino Tomaz ${ }^{1}$, Bruno Portela Brasileiro², \\ Luiz Alexandre Peternelli³, Márcio Henrique Pereira Barbosa ${ }^{1}$
}

\author{
${ }^{1}$ Universidade Federal de Viçosa/UFV, Departamento de Fitotecnia/DFT, Viçosa, MG, Brasil \\ ¿Universidade Federal do Paraná/UFPR, Departamento de Fitotecnia e Fitossanitarismo/DFF, Curitiba, PR, Brasil \\ ${ }^{3}$ Universidade Federal de Viçosa/UFV, Departamento de Estatística/DET, Viçosa, MG, Brasil \\ ${ }^{*}$ Corresponding author: guilhermepimentel91@gmail.com \\ Received in February 2, 2017 and approved in June 6, 2017
}

\begin{abstract}
The sugarcane borer Diatraea saccharalis Fabr. (Lepidoptera: Crambidae) is one of the most important pests of sugarcane in the Americas. The purpose of this study was to assess multiple resistance traits in eight sugarcane genotypes against $D$. saccharalis, including five commercial cultivars and three exotic germplasm with potential to serve as resistance sources against this pest. The oviposition preference was assessed by using both free-choice and non-choice tests. The performance of both early stage larvae feeding on the leaves and late stages larvae feeding within the stalks were also assessed. There were differences among genotypes for number of both eggs and egg cluster in the free-choice test while no differences in non-choice test were observed. There were also differences in survival of early stage larvae feeding on the leaves, foliar injury rating and stalk damage. The genotype IM76-228 was the least preferred for oviposition and it seems that leaf width had some influence on adults' preference rather than greening of the leaves. IM76-228 and RB867515 causes higher mortality of early stage larvae feeding in the stalks while IM76-228 and RB985523 had lower damage in both leaves and stalks. The genotype IM76-228 was the most resistant to $D$. saccharalis and could serve as genes sources for resistance in sugarcane breeding programs.
\end{abstract}

Index terms: Saccharum spp.; Diatraea saccharalis; host-plant resistance.

\section{RESUMO}

A broca da cana-de-açúcar Diatraea saccharalis Fabr. (Lepidoptera: Crambidae) é uma das mais importantes pragas da cana-de-açúcar nas Américas. Este estudo foi realizado para investigar múltiplos traços de resistência em oito genótipos de cana-de-açúcar contra $D$. saccharalis, incluindo cinco cultivares comerciais e três germoplasmas exóticos com potencial para servir de fontes de resistência contra esta praga. A preferência de oviposição foi avaliada por meio de testes de escolha livre e de não-escolha. O desempenho de larvas de estágio inicial que se alimentam das folhas e de larvas de estádio tardio alimentando-se com os colmos também foi avaliado. Houve diferenças entre os genótipos para o número de ovos e posturas no teste de livre escolha, enquanto não foram observadas diferenças no teste de não-escolha. Houve também diferenças na sobrevivência de larvas de estádios iniciais que se alimentam das folhas, índice de lesões e dano no colmo. O genótipo IM76-228 foi o menos preferido para a oviposição e parece que a largura da folha teve alguma influência sobre a preferência dos adultos em vez da intensidade de verde das folhas. IM76-228 e RB867515 provocaram uma mortalidade mais elevada de larvas de estádio inicial alimentando-se dos colmos, enquanto que IM76-228 e RB985523 apresentaram menor dano nas folhas e nos colmos. O genótipo IM76-228 foi o mais resistente a $D$. saccharalis e pode servir como fonte de genes para resistência em programas de melhoramento de cana-de-açúcar.

Termos para indexação: Saccharum spp.; Diatraea saccharalis; resistência de plantas hospedeiras.

\section{INTRODUCTION}

The sugarcane borer, Diatraea saccharalis Fabr. (Lepdoptera: Crambidae), is a major pest of sugarcane in the American continent (Posey et al., 2006; DinardoMiranda, 2008; Vargas; Gómez; Michaud, 2015). Early-instar larvae feed on the leaf parenchyma and leafsheaths while older larvae bore into the stalks reducing sucrose content and weight and facilitating colonization by fungi that causes red rot disease, which indirectly reduce the yield and quality of sugar and ethanol (Long; Hensley, 1972; Macedo; Botelho, 1988). The use of sugarcane cultivars more resistant to $D$. saccharalis is essential for the Integrated Pest Management of this pest as it emerges as an economically and environmentally effective control measure (Milligan; Balzarini; White, 2003; Posey et al., 2006; Dinardo-Miranda, 2008; Vargas; Gómez; Michaud, 2015). 
Some studies have identified resistance traits in sugarcane cultivars. Sosa Jr. $(1988,1990)$ observed that glabrous genotypes are preferred for oviposition over pubescent cultivars. However, Dinardo-Miranda et al. (2012) found no correlation between oviposition preference and trichomes. In addition, the presence of trichomes affected mobility of young larvae, which could increase larval mortality due to greater exposure to environmental conditions (Sosa Junior., 1988). However, Coburn and Hensley (1972) attributed the higher mortality of young larvae to tightness of the leaf-sheaths while White (1993a) attributed it to the presence of physical or chemical barriers preventing or delaying larvae entrance into the stalks. Other studies also suggest that antibiosis is related with presence of chemical compounds (Souza et al., 2013, White et al., 2011). In addition, some sugarcane genotypes present low stalk damage, adult emergence and larval weight (Dinardo-Miranda et al., 2012). These studies suggest that sugarcane cultivars express resistance via complex contributions and interactions of several components (Milligan; Balzarini; White, 2003). Thus, the three modalities of resistance: non-preference (i.e., antixenosis), antibiosis, and tolerance (Painter, 1951; Kogan; Ortman, 1978; Smith, 2005) seem to be present.

Despite of the knowledge about resistance traits in sugarcane genotypes, there are only a few studies of resistance of Brazilian genotypes to $D$. saccharalis found in the literature (Dinardo-Miranda et al., 2012, 2013; Souza et al., 2013). Therefore, the purpose of this study was to assess multiple resistance traits in eight sugarcane genotypes against $D$. saccharalis, including five commercial cultivars and three exotic germplasm with potential to serve as resistance sources against this pest.

\section{MATERIAL AND METHODS}

\section{Insects and plants}

The insects used in all experiments were obtained from a stock colony reared in artificial diet (Hensley; Hammond, 1968) with slight modifications (Araújo et al. 1985). The colony originated from a pool of field-collected and laboratory-reared larvae and inbreeding depression was minimized by maintaining large population sizes and periodically introducing field-collected sugarcane borers.

The eight genotypes used in this study were obtained from the sugarcane germplasm unit of the Brazilian Inter-University Network for the Development of Sugarcane Industry (RIDESA, Brazil) and included two genotypes of Saccharum robustum (IM76-228 and
IJ76-314), a cultivar from Argentina (TUC71-7), and five commercial varieties in Brazil (RB867515, RB825336, RB985523, SP80-1842 and SP80-3280). The five commercial varieties used in this study are widely grown in Brazil, especially RB867515 that is grown in $26 \%$ of cultivated area in the states of Mato Grosso and São Paulo. They also show different responses to borer attack: RB867515 shows some level of resistance; RB825336, RB985523, and SP80-3280 are susceptible, and SP801842 is extremely susceptible. The other genotypes were chosen because they have shown some resistance against some pests and can be crossed with commercial varieties to provide genes of resistance against pests.

Single-node stem cuttings containing one lateral bud were placed in plastic trays filled with germination substrate (Tropstrato, Vida Verde Indústria e Comércio de Insumos Orgânicos Ltda, Mogi Mirim, SP, Brazil) in order to obtain experimental sugarcane plants. After 45-60 days, the seedlings were transplanted to plastic pots $(500 \mathrm{ml}$ for oviposition tests and $7 \mathrm{~L}$ for larval performance tests), containing soil and maintained in a greenhouse $\left(26 \pm 10^{\circ} \mathrm{C}\right.$; $75 \pm 20 \% \mathrm{RH} ; 12 \pm 2 \mathrm{~h}$ photoperiod) to avoid natural insect infestation. A single cutting was transplanted to each pot. Limestone and fertilizer were applied to adjust soil $\mathrm{pH}$ and achieve suitable growth conditions (Korndorfer; Ribeiro; Andrade, 1999). Plants were irrigated using drippers at 0.5 to $2.0 \mathrm{l} / \mathrm{pot} / \mathrm{day}$. Three days before the experiments, the plants were brought to the laboratory for acclimation for laboratory conditions $\left(26 \pm 2{ }^{\circ} \mathrm{C}, 70 \pm 10 \% \mathrm{RH}\right.$, and $12 \mathrm{~h}$ photoperiod).

\section{Oviposition preference}

\section{Free-choice test}

Fifty-day-old plants of the eight genotypes previously described were enclosed in wooden cages $(0.5 \mathrm{~m}$ width $\times 0.8 \mathrm{~m}$ length $\times 1.0 \mathrm{~m}$ height $)$ covered with anti-aphid cloth. Then, 24 couples of newly-emerged adults were released into each cage. In order to avoid that excessive number of eggs inhibited oviposition, after 24 hours, all plants were removed from the cages and replaced by new plants of the same genotypes. Then, after 24 hours, the new plants were removed from the cages for assessing oviposition preference. The data of the two sets of plants were combined for statistical analysis.

Due to the difficulty to count total number of eggs per plant as eggs are often overlapped in the cluster, the egg clusters were classified in single egg, small, medium or large clusters (SE, SC, MC and LC, respectively), and 
the number of each cluster class was recorded. Then, when the eggs were at "black-stage" (when the cephalic capsule of the larvae are visible), the number of eggs in 60 clusters of each class (SC, MC and LC) were counted to estimate the mean number of eggs in each class. Then, the total number of eggs per plant was estimated as TE $=$ number of $\mathrm{SE}+$ number of $\mathrm{SC} \times$ mean number of eggs in $\mathrm{SC}+$ number of $\mathrm{MC} \times$ mean number of eggs in $\mathrm{MC}+$ number of LC $\times$ mean number of eggs in LC. The total number of egg clusters per plant was calculated as TEC $=\mathrm{SE}+\mathrm{SC}+\mathrm{MC}+\mathrm{LC}$. In addition, the width and the greening of leaf +1 were assessed according to the Kujiper classification (Cheavegatti-Gianotto et al., 2011). The greening of the leaves was measured with a Soil Plant Analysis Development (SPAD) (Minolta Corp ${ }^{\circledR}$ ) and the leaf width was measured by using a digital caliper.

The experiment was carried out in a randomized block design with five replicates per treatment. The distribution of the plants within the cages was different among the blocks to exclude environmental effects. The experimental units were composed by both plants of the first and second sets of plants.

\section{Non-choice test}

Based on the results from free-choice test, only the genotypes SP80-3280, RB867515 and IM76-228 were used in non-choice test. Four plants of each genotype were enclosed in separate cages and 12 new-emerged couples of adults were released into each cage. As in the free-choice test, the plants were replaced by other plants of the same genotype at 24 hours after infestation and new plants were removed from the cages after 24 hours. The number of SE, SC, MC and LC as well as the estimate of TEC and TC were assessed.

The plots were composed by eight plants (four plants per cage $x$ two sets of plants. Due to the difficulty in obtaining sufficient numbers of adults for simultaneous release, borer couples were released on different dates for each replicate. Therefore, the experiment was carried out using a randomized block statistical design with four replicates.

\section{Larval performance}

Two experiments were performed to assess larval performance in the genotypes under study: one to assess performance of early stage larvae during the time they feed on the leaves and leaf-sheaths and other experiment to assess performance of late-stages larvae, during the time they feed within the stalks. In the first experiment, four-month-old plants were used. However, in the second experiment, six-month-old plants were used in order to obtain well-developed stalks for the experiments.

\section{Performance of early stage larvae}

Pots containing four-month-old single plants of each genotype were placed in trays containing water to prevent ants attack. Then, 30 neonates of $D$. saccharalis were transferred to the youngest leaf by using a fine-hair brush. After six days, larval survival and leaf damage were assessed. Damage was assessed by using an injury rating ranging from 1 to 5 , with score 1 representing the lowest level (i.e., few small holes on young leaves) and 5 the highest one (i.e., youngest leaf dead). The experiment was performed in a randomized block design with four replicates per treatment. The experimental units were composed by a pot containing a single plant.

\section{Performance of late-stages larvae}

Six-month-old plants of each genotype were harvested, their leaf sheaths removed, and a $40-\mathrm{cm}$ section of the upper stalk portion was placed in a 2-L cylindrical cage made of polyethylene terephthalate bottles. The cage had a side-opening covered with organdy cloth for ventilation. Twenty 15 -day-old larvae ( $4^{\text {th }}$ instar) were weighted, transferred to each cage and maintained in a growth chamber at $26 \pm 2{ }^{\circ} \mathrm{C}, 70 \pm 10 \% \mathrm{RH}$, and $12 \mathrm{~h}$ photoperiod. After 15 days, we dissected the stalk sections recording survival, larval weight, percentage of pupation and the tunnel length in the stalks. We calculated the weight gain of larvae for each replicate (i.e. cage) using the formula: ((final total weight) / (final number of insects)) - ((initial total weight) / (initial number of insects)). The stalk damage was assessed as percentage of the stalk length consumed by larvae and it was calculated as (tunnel length / stalk length)*100. The experiment was carried out in a completely randomized design with four replicates per treatment. The experimental units were composed by a cage containing one stalk.

\section{Data analysis}

For statistical analysis, counting data were transformed into square root $(\mathrm{x}+1)$ and percentage data into arcsine square root $(\mathrm{x} / 100)$ in order to meet Anova assumptions. The data were then submitted to Anova and the treatment means were compared by Tukey's test. The software R was used for statistical analysis. Pearson's correlation analysis between oviposition preference data and SPAD and leaf width were also performed. 


\section{RESULTS AND DISCUSSION}

\section{Oviposition preference}

\section{Free-choice test}

According to the counting of the eggs in cluster samples, the SC, MC and LC had in average 10, 25 and 63 eggs, respectively. These values were similar to that found by Dinardo-Miranda et al. (2012), who found averages of 13, 27 and 60 eggs respectively in SC, MC and LC. Most of the egg clusters were oviposited by $D$. saccharalis on the upper part of the leaves, which was also observed by Hamm et al., (2012) in rice cultivars.

There were significant differences among genotypes for number of egg clusters $(\mathrm{F}=6.05 ; \mathrm{df}=7,28 ; P=0.0002)$ and number of eggs per plants $(\mathrm{F}=7.18 ; \mathrm{df}=7,28 ; P<$ $0.0001)$. The genotype IM76-228 was the least preferred for ovipostion by $D$. saccharalis as this genotype had the lowest numbers of both eggs and egg clusters. On the other hand, RB867515 had the highest numbers of both eggs and egg clusters, followed closely by SP80-3280 (Figures 1A, 1B).

There were also significant difference among genotypes in leaf width $(\mathrm{F}=23.12 ; \mathrm{df}=7,28 ; P<0.0001)$ and $\operatorname{SPAD}(\mathrm{F}=4.77 ; \mathrm{df}=7,28 ; P=0.0013)$. The genotype RB867515 had the widest leaves, while IJ76-314, IM76228, RB825336 and TUC71-7 had the narrowest leaves (Figure 2A). On the other hand, the genotype IM76-228 had the highest SPAD values while RB825336 and SP803280 had the lowest values (Figure 2B). There were high positive correlations between leaf width and number of egg clusters $(r=0.85)$ and number of eggs $(r=0.81)$. Although, no correlations between SPAD and number of eggs and egg clusters were found $(P>0.05)$.

The non-preference of a plant by a herbivore also known as antixenosis (Kogan; Ortman, 1978) has been related to several biochemical and physical aspects of plants such as chemical defenses, trichome density and type, tissue thickness, shape, and color (Smith, 2005; Schoonhoven; Loon; Dicke, 2005). In sugarcane, Sosa Jr. (1988, 1990) observed that glabrous cultivars were more preferred by D. saccharalis for oviposition than pubescent cultivars, indicating the importance of trichomes in oviposition preference. However, Dinardo-Miranda et al. (2012) found no correlation between trichomes and oviposition preference by $D$. saccharalis suggesting that other traits were more important. In the present study, the presence of trichomes in IM76-228 may be partly responsible for lower oviposition on this genotype. Although, the large correlation between leaf width and number of eggs and egg clusters indicates that leaf width also affects preference by $D$. saccharalis.
A

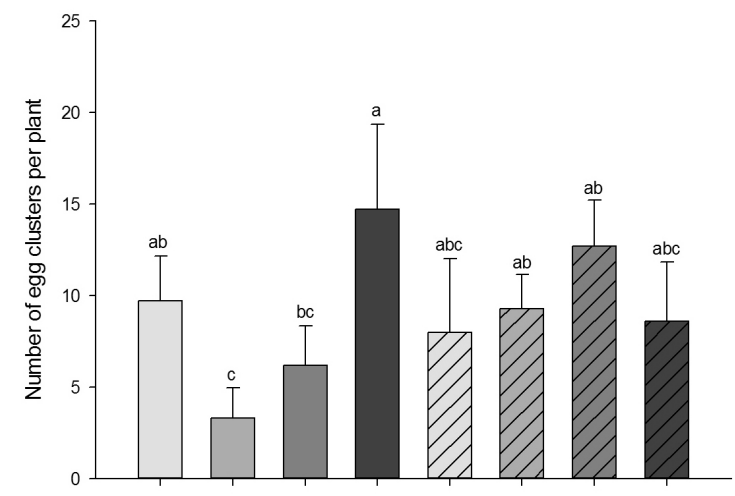

B

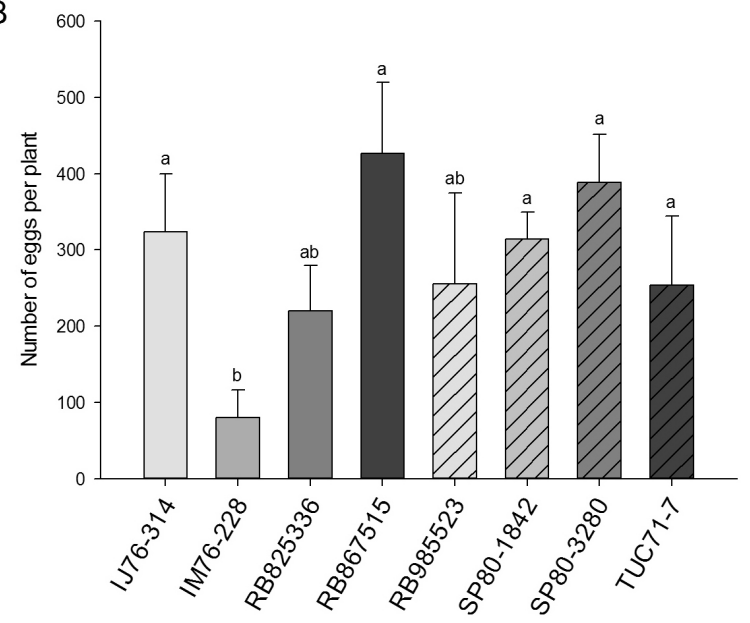

Figure 1: Oviposition preference by $D$. saccharalis larvae in 50-day-old plants of eight sugarcane genotypes in a free-choice test. The bars accompanied by the same letter are not different according to Tukey's test protected by Anova $(P<0.05)$.

The SPAD index measures the greening of the leaves, which is correlated with chlorophyll (Guimarães et al., 1999; Argenta et al., 2001) and nitrogen content (Zebarth et al., 2003; Fontes; Araujo, 2007), providing an indication of nutritional status of the leaves. Stefanescu et al. (2006) found that females of Euphydryas aurinia (Lepidoptera: Nymphalinae: Melitaeini) select the greenest leaves of Lonicera implexa (Caprifoliaceae) in agreement with other studies with butterflies (Scherer; Kolb, 1987; Kelber, 1999). Taylor and Forno (1987) observed the preference of Samea multiplicalis Guenee (Lepidoptera: Pyralidae) for oviposition and higher survival of early stage larvae in plants with higher nitrogen content. However, in this study, there was no correlation between SPAD index and oviposition preference by $D$. saccharalis. Furthermore, 
the least preferred genotype IM76-228 had the highest SPAD values, indicating that the greening of the leaves does not affect oviposition preference by $D$. saccharalis in sugarcane. It is likely that because of their nocturnal habits, adults of $D$. saccharalis use other clues such as plant volatiles rather than visual clues to select the host plants.

\section{Non-choice test}

Based on the results of the free-choice test, the non-choice experiment was carried out only with the most (SP80-3280 and RB867515) and the least (IM76-228) preferred genotypes by the moths. There were no differences among genotypes for both number of eggs clusters and number of eggs $(\mathrm{P}>0.05)$. It indicates that in the absence of more favorable host plants, the least preferred sugarcane genotypes are not totally discarded (Table 1).

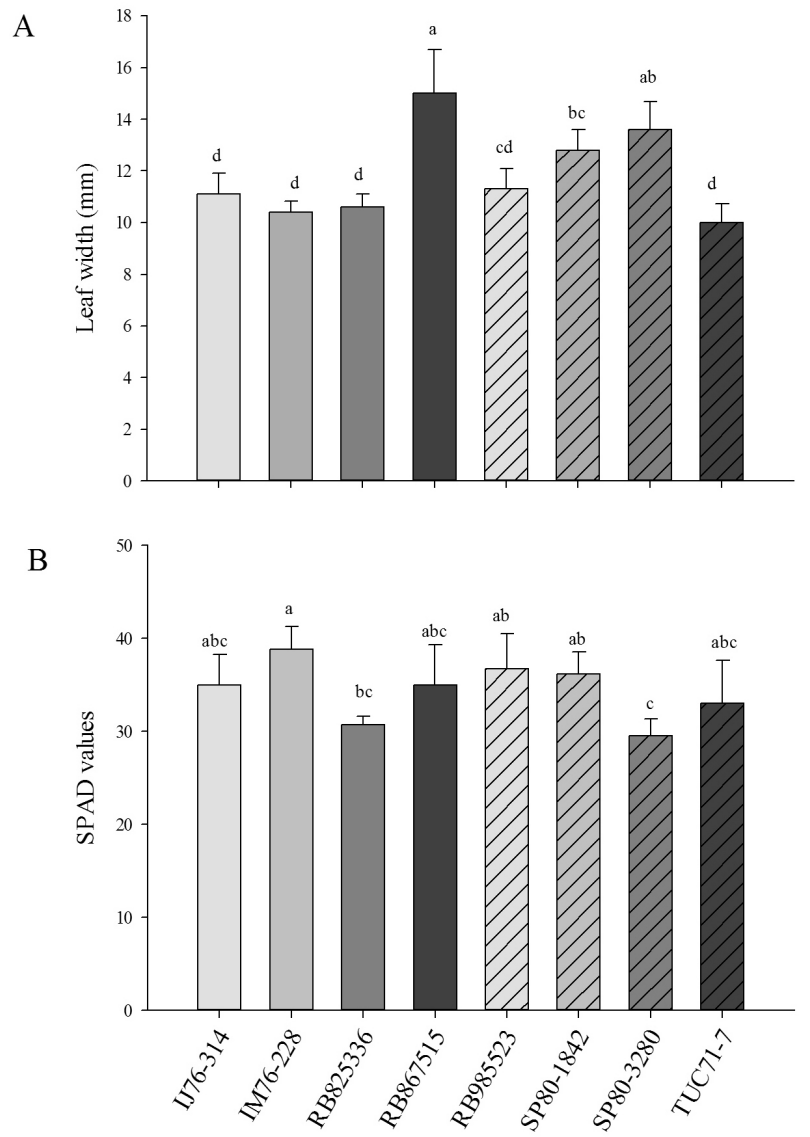

Figure 2: A) Mean width and B) SPAD values of the leaf +1 (according to Kujiper classification) in 50-dayold plants of eight sugarcane genotypes. The bars accompanied by the same letter are not different according to Tukey's test protected by Anova $(P<0.05)$.
Table 1: Oviposition preference by $D$. saccharalis moths in three sugarcane genotypes in non-choice tests.

\begin{tabular}{ccc}
\hline Genotype & TEC & TE \\
\hline SP80-3280 & $2.59 \pm 1.69$ & $67.51 \pm 39.97$ \\
RB867515 & $7.28 \pm 8.39$ & $73.64 \pm 77.64$ \\
IM76-228 & $0.78 \pm 0.41$ & $32.69 \pm 16.68$ \\
CV(\%) & 149.47 & 86.46 \\
p-value & 0.1337 & 0.5646 \\
\hline
\end{tabular}

TEC $=$ Total number of egg clusters per plant, TE $=$ Total number of eggs per plant (Mean $\pm \mathrm{SE}$ ).

\section{Larval performance}

\section{Performance of early stage larvae}

There were significant differences among genotypes for both injury rating $(\mathrm{F}=4.39 ; \mathrm{df}=7,32 ; P=0.02)$ and survival of early stage larvae feeding on leaves and leafsheaths $(\mathrm{F}=2.99 ; \mathrm{df}=7,32 ; P=0.016)$. The genotype SP80-1842 had the highest injury rating while IM76-228 had the lowest mean, indicating that this genotype was less consumed by early stage larvae (Figure $3 \mathrm{~A}$ ). On the other hand, SP80-3280 had the highest larval survival while RB867515 and IM76-228 had the lowest means, suggesting the presence of antibiosis on these genotypes (Figure 3B).

Higher mortality of young larvae in sugarcane genotypes is known to be a resistance trait in sugarcane genotypes (Coburn; Hensley, 1972; White, 1993a). Despite the fact that genotype RB867515 was the most preferred for oviposition, this genotype had the lowest survival of early stage larvae, which was close to IM76-228 and nearly 10-fold lower than SP803280. These results are in contrast to Sidhu, Stout and Blouin (2013), which found high correlation between larval performance and oviposition preference of $D$. saccharalis in rice cultivars in agreement with other studies (Nylin; Janz, 1993; Barker; Maczka, 1996). Although, according to Lara (1991), the most preferred cultivar for oviposition is not always the most adequate to the larvae. Dinardo-Miranda et al. (2012) observed that in sugarcane the most preferred genotypes for oviposition by $D$. saccharalis were not the most favorable for larval development. Therefore, it seems that both oviposition preference and larval performance act in different ways in sugarcane resistance against $D$. saccharalis. 
A

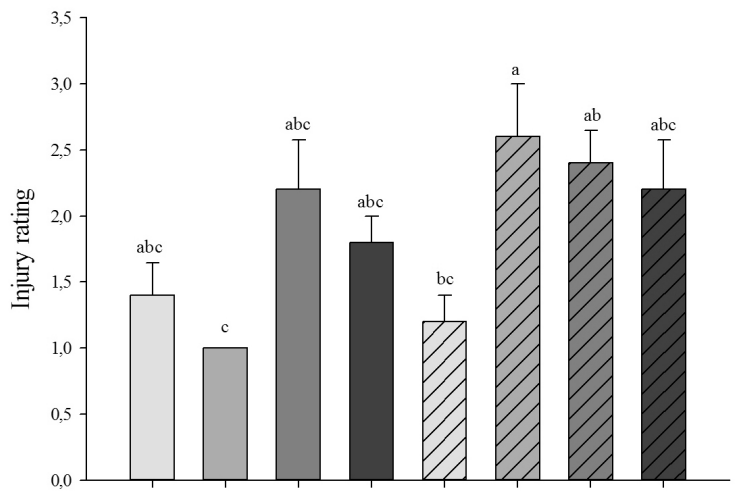

B

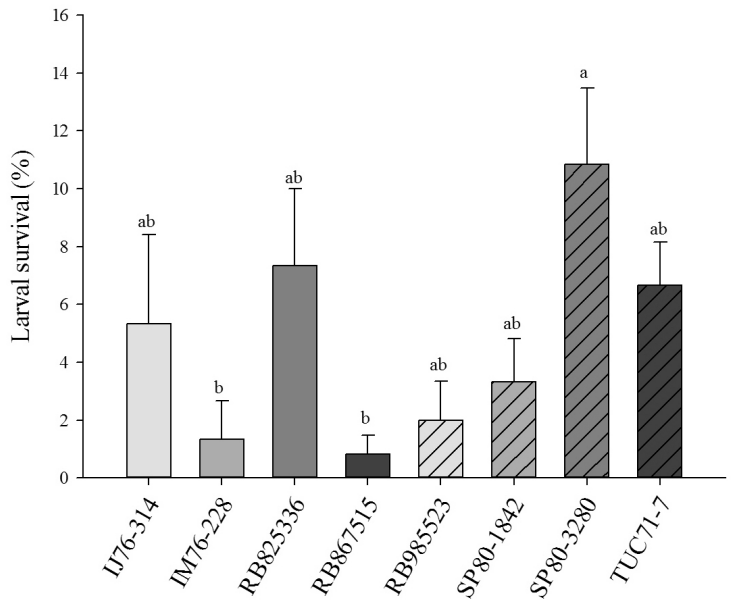

Figure 3: A) Injury rating and B) Survival of early stage $D$. saccharalis larvae at six days after infestation in leaves of four-month-old plants of eight sugarcane genotypes. The bars accompanied by the same letter are not different according to Tukey's test protected by Anova.

\section{Performance of late-stages larvae}

There were no differences among genotypes for survival of late-stages larvae feeding in the stalks, weight gain of larvae and percentage of pupation $(P>0.05)$. These results are in contrast to previous studies, which indicated differences among sugarcane genotypes in larval survival and weight and pupation (White et al., 2011; Dinardo-Miranda et al., 2012; Souza et al., 2013), suggesting the presence of antibiosis or feeding deterrence in stalks of some sugarcane genotypes.

However, there were significant differences among genotypes for percentage of stalk length consumed by larvae $(\mathrm{F}=4.69 ; \mathrm{df}=7,32 ; P=0.001)$. The genotype RB867515 presented the highest stalk damage, while SP80-3280, IJ76314, IM76-288, RB985523, and TUC71-7 had the lowest means (Figure 4).

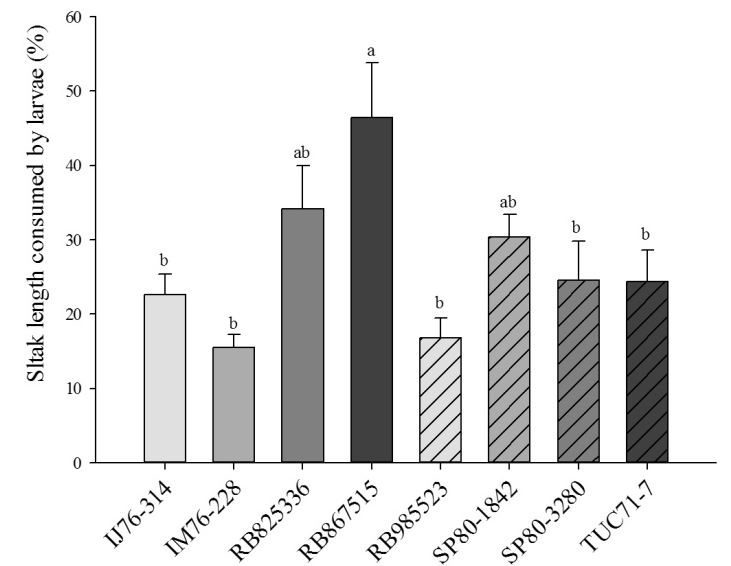

Figure 4: Stalk damage or percentage of stalk length consumed by $D$. saccharalis larvae at 15 days after infestation with 15-day-old larvae. The bars accompanied by the same letter are not different according to Tukey's test protected by Anova $(P<0.05)$.

The genotypes RB985523 and IM76-228 exhibited the lowest foliar and stalk damages, indicating that these genotypes have some traits that reduce consumption by larvae in both tissues. However, SP80-1842 had the highest leaf damage while RB867515 had the highest stalk damage. This result confirm the fact that resistance in both leaves and stalks act in different ways. Moreover, these results are in agreement with White (1993b), which found no correlation between an injury rating (based in leaf damage, broken tops, etc.) and stalk damage, suggesting that different resistance traits are present in either leaves or stalks.

\section{Overall resistance of sugarcane genotypes to $D$. saccharalis}

In summary, the results from this study are in agreement with previous studies indicating that resistance of sugarcane cultivars to D. saccharalis is composed by complex contributions and interactions of several components. Thus, both resistance mechanisms (antibiosis and antixenosis) are present in sugarcane resistance to $D$. saccharalis (Milligan; Balzarini; White, 2003).

Our results indicates that the genotype IM76228 possess antixenosis and resistance in both leaves and stalks against $D$. saccharalis. This genotype belongs to a $S$. robustum species, which provided minor contributions toward the development of some modern sugarcane varieties. However, this genotype can be used in sugarcane breeding programs as donor of resistance sources against pests such as $D$. saccharalis (Cheavegatti-Gianotto et al., 2011). 


\section{CONCLUSIONS}

The sugarcane genotypes present different resistance traits against $D$. saccharalis. The genotype IM76-228 is the least preferred by adults for oviposition, IM76-228 and RB867515 causes higher mortality of early stage larvae feeding on the leaves, and IM76-228 and RB985523 had lower damage in both leaves and stalks.

\section{ACKNOWLEDGEMENTS}

We thank the technical assistance provided by the Inter-University Network for the Development of Sugarcane Industry in Brazil (RIDESA). The financial support provided by the National Council of Scientific and Technological Development (CNPq), CAPES Foundation (Brazilian Ministry of Education), the Minas Gerais State Foundation for Research Aid (FAPEMIG), and the RIDESA-UFV Sugarcane Breeding Program were greatly appreciated and acknowledged here.

\section{REFERENCES}

ARAÚJO, J. R. et al. Nova dieta artificial para criação da Diatraea saccharalis (Fabr.). Saccharum, 36:45-48, 1985.

ARGENTA, G. et al. Relationship of reading of portable chlorophyll meter with contents of extractable chlorophyll and leaf nitrogen in maize. Revista Brasileira de Fisiologia Vegetal, 13(2):158-167, 2001.

BARKER, A.; MACZKA, C. J. M. The relationships between host selection and subsequent larval performance in three free-living graminivorous sawflies. Ecological Entomology, 21(4):317-327, 1996.

CHEAVEGATTI-GIANOTTO, A. et al. Sugarcane (Saccharum X officinarum): A reference study for the regulation of genetically modified cultivars in Brazil. Tropical Plant Biology, 4(1):6289, 2011.

COBURN, G. E.; HENSLEY, S. D. Differential survival of Diatraea saccharalis (F.) larvae on two varieties of sugarcane. Proceedings Internacional Society of Sugar Cane Technologists, 14:440-444, 1972.

DINARDO-MIRANDA, L. L. Pragas. In: DINARDO-MIRANDA, L. L.; VASCONCELOS, A. C. M.; LANDELL, M. G. A. (Ed.). Cana-deaçúcar. Campinas: Instituto Agronômico, 2008. p.349-404.

DINARDO-MIRANDA, L. L. et al. Resistance of sugarcane cultivars to Diatraea saccharalis. Pesquisa Agropecuaria Brasileira, 47(1):1-7, 2012.
DINARDO-MIRANDA, L. L. et al. Reação de cultivares de canade-açúcar à broca do colmo. Bragantia, 72(1):29-34, 2013.

FONTES, P. C. R.; ARAÚJO, C. Adubação nitrogenada de hortaliças: Princípios e práticas com o tomateiro. Viçosa: Editora UFV, 2007. 148p.

GUIMARÃES, T. G. et al. Teores de clorofila determinados por medidor portatil e sua relação com formas de nitrogênio em folhas de tomateiro cultivados em dois tipos de solo. Bragantia, 58(1):209-216, 1999.

HAMM, J. C. et al. Oviposition behavior of Diatraea saccharalis (Lepidoptera: Crambidae) on different rice cultivars in Louisiana. Environmental Entomology, 41(3):571-577, 2012.

HENSLEY, S. D.; HAMMOND, A. H. Laboratory techniques for rearing the sugar cane borer on an artificial diet. Journal of Economic Entomology, 61(6):1742-1743, 1968.

KELBER, A. Ovipositing butterflies use a red receptor to see green. Journal of Experimental Biology, 202(19):26192630, 1999.

KOGAN, M.; ORTMAN, E. E. Antixenosis-a new term proposed to define Painter's "nonpreference" modality of resistance. Bulletin of the Entomological Society of America, 24(2):175-176, 1978.

KORNDORFER, G. H.; RIBEIRO, A. C.; ANDRADE, L. A. de B. Canade-açúcar. In: RIBEIRO, A. C.; GUIMARÃES, P. T. G.; ALVAREZ V., V. H. (Ed.). Recomendações para o uso de corretivos e fertilizantes em minas gerais: $5^{\text {a }}$ aproximação. Viçosa: Editora UFV, 1999. p.25-32.

LARA, F. M. Princípios de resistência de plantas aos insetos. São Paulo: Ícone, 1991. 336p.

LONG, W. H; HENSLEY, S. D. Insect pests of sugarcane. Annual Review of Entomology, 17(1):149-176, 1972.

MACEDO, N.; BOTELHO, P. S. M. Controle integrado da broca da cana-de-açúcar, Diatraea saccharalis (Fabr., 1794) (Lepidoptera: Pyralidae). Brasil Açucareiro, 106(2):214, 1988.

MILLIGAN, S. B.; BALZARINI, M.; WHITE, W. H. Broad-sense heritabilities, genetic correlations, and selection indices for sugarcane borer resistance and their relation to yield loss. Crop Science, 43(5):1729-1735, 2003.

NYLIN, S.; JANZ, N. Oviposition preference and larval performance in Polygonia c-album (Lepidoptera: Nymphalidae): The choice between bad and worse. Ecological Entomology, 18(4):394-398, 1993. 
PAINTER, R. H. Insect resistance in crop plants. Macmillan, New York, 1951. p.481.

POSEY, F. R. et al. Sugarcane borer (Lepidoptera: Crambidae) management threshold assessment on four sugarcane cultivars. Journal of Economic Entomology, 99(3):966971, 2006.

SCHERER, C.; KOLB, G. Behavioral experiments on the visual processing of color stimuli in Pieris brassicae $\mathrm{L}$. (Lepidoptera). Journal of Comparative Physiology A, 160(5):645-656, 1987.

SCHOONHOVEN, L. M.; VAN LOON, J. J. A.; DICKE, M. Plants as insect food: Not the ideal. In: Insect Plant Biology, Oxford University Press on Demand, 2005. p.99-134.

SIDHU, J. K.; STOUT, M. J.; BLOUIN, D. C. Performance and preference of sugarcane borer, Diatraea saccharalis, on rice cultivars. Entomologia Experimentalis et Applicata, 149(1):67-76, 2013.

SMITH, C. M. Plant resistance to arthropods: Molecular and conventional approaches. The Netherlands: Springer, 2005. 423p.

SOSA JUNIOR, O. Pubescence in sugarcane as a plant resistance character affecting oviposition and mobility by the sugarcane borer (Lepidoptera: Pyralidae). Journal of Economic Entomology, 81(2):663-667, 1988.

SOSA JUNIOR, O. Oviposition preference by the sugarcane borer (Lepidoptera: Pyralidae). Journal of Economic Entomology, 83(3):866-868, 1990.
SOUZA, J. R. de et al. Divergência genética de cultivares de cana-de-açúcar quanto à resistência a Diatraea saccharalis. Semina: Ciências Agrárias, 34(6Supl1):3367-3376, 2013.

STEFANESCU, C. et al. Females of the specialist butterfly Euphydryas aurinia (Lepidoptera: Nymphalinae: Melitaeini) select the greenest leaves of Lonicera implexa (Caprifoliaceae) for oviposition. European Journal of Entomology, 103(3):569-574, 2006.

TAYLOR, M. F. J.; FORNO, I. W. Oviposition preferences of the salvinia moth Samea multiplicalis Guenee (Lep., Pyralidae) in relation to hostplant quality and damage. Journal of Applied Entomology, 104(1-5):73-78, 1987.

VARGAS, G.; GÓMEZ, L. A.; MICHAUD, J. P. Sugarcane stem borers of the Colombian Cauca River Valley: Current pest status, biology, and control. Florida Entomologist, 98(2):728-735, 2015.

WHITE, W. H. Movement and establishment of sugarcane borer (Lepidoptera: Pyralidae) larvae on resistant and susceptible sugarcane. Florida Entomologist, 76:465-473, 1993a.

WHITE, W. H. Cluster analysis for assessing sugarcane borer resistance in sugarcane line trials. Field Crops Research, 33(1-2):159-168, 1993b.

WHITE, W. H. et al. Registration of two sugarcane germplasm clones with antibiosis to the sugarcane borer (Lepidoptera: Crambidae). Journal of Plant Registrations, 5(2):248-253, 2011.

ZEBARTH, B. J. et al. Mapping spatial variation in potato nitrogen status using the N sensor. Acta Horticulturae, 627:267$273,2003$. 